\title{
末期慢性腎不全に対する血液浄化療法の外来通院導入
}

\author{
大谷仁美* 岡本 幸子* 牧野かをる* 平川ひとみ* \\ 平岡 真裕弥* 西垣 恭美* 竹村 伸子* 大石育子* \\ 宇都宮正子* 西村昌美* 小木幸人* 今田聰雄** \\ 近畿大学人工透析部*, 同第 3 内科**
}

(昭和 60 年 11 月 1 日受付)

key words：末期慢性腎不全，血液浄化療法，外来導入，社会復㷌

〈要旨〉

現在では，外来通院のままで血液浄化療法を開始することも可能である．とこで安全な外来導入法を確立するため の看護上の問題点を外来導入例 (外来群) と入院導入例 (入院群) について比較検討した. 1980 年から 1984 年の 5 年 間に当院で浄化療法を開始した外来群 13 例と導入時に入院をしていた症例の中から基礎疾患, 性別および職業が一致 し，年齢の似かよった入院群 13 例の計 26 例を対象とした。

血圧, 体重, 生化学的検查值を導入前, 導入後 4 週および 12 週で比較した。弚の結果, 弚れらの数値には両群間で 有意差はなかった。アンケート調查で精神面への影響, 社会復帰の程度を比較した。一生透析を続けなければならな いこと，食事制限，さらにいつまで生きられるかに対する不安は両群とも $75 \%$ の高率に認められた。穿刺時の痛み， 体外循環に対する不安は入院中に他の患者から誤った情報として伝えられるため, 入院群に多かった。一方社会復帰 は, 完全社会復帰が入院群の $26 \%$ に対し外来群は $64 \%$ と高率であった。また社会復帰までの期間でも, 外来群の方が 短期間で導入前の仕事に復帰し, 弚れを維持していた。

治療の目的の 1 つでもある社会復帰は外来導入が有利であった。外来導入を安全に施行するためには, 慢性腎不全 の保存療法期から浄化療法および日常生活に対する正確な情報を医療スタッフが一貫して患者に与えることが必要だ と思われた，弚のためには，チェックリストを使用し，患者の理解度に合わせて，スタッフが同一内容の指導を行う ベきだと考えられた。

\section{Advantage of theraputic blood purification in outpatients with end-stage renal diseases}

Hitomi Ohtani*, Kyomi Nishigaki*, Nobuko Takemura*, Hitomi Hirakawa*, Mayumi Hiraoka*, Kaoru Makino*, Sachiko Okamoto*, Ikuko Ohishi*, Masako Utsunomiya*, Masami Nishimura*, Yukito Koghi*, and Akio Imada, M. D.**

Department of Artificial Dialysis, Kinki University Hospital*; The Third Department of Internal Medicine, Kinki University School of Medicine**

Therapeutic blood purification can now be recommended for outpatients with end-stage renal disease (ESRD). Biochemical examination values, mental effects and degree of social rehabilitation were compared in two groups of patients with ESRD. 13 outpatients ( 8 males and 5 females, mean age $45 \pm 12.1$ years-Out-G) underwent therapeutic blood purification in our hospital during the 5 years from 1980 to 1984 . In 13 inpatients (8 males and 5 females, mean age $43 \pm 10.3$ years $-\mathrm{In}-\mathrm{G}$ ), age, sex and other factors were simila to Out-G. Measurement of blood pressure and body weight and biochemical examination were performed before and 4 and 12 weeks after initiation of the therapy. No significant differences were observed between the two groups. Mental effects and degree of social rehabilitation were examined via questionnaire. Of mental effects, pain at puncture of blood access and anxiety concerning extracorporeal circulation were the most frequent complaints among the $\mathrm{In}-\mathrm{G}$. This seemed

大谷 仁美 近畿大学医学部附属病院人工透析部

干 589 南河内郡狭山町西山380（0723-66-0221） 
to come from erroneous information concerning the therapy provided by other inpatients. Anxieties over the possible need of dialysis therapy for the rest of their lives, dietary restrictions and length of survival were noted in a high $75 \%$ of each group. Of the Out-G, $64 \%$ were completely rehabilitated, while only $26 \%$ of the In-G was. As for duration until social rehabilitation, the Out-G returned to their jobs within shorter terms, and continued their work. It is concluded that initiation of therapeutic blood purification in outpatients with ESRD is more advantageous for social rehabilitation.

\section{緒言}

入院導入が原則とされていた末期慢性腎不全に対する 血液浄化療法は 10 年以上の長期生存が可能 ${ }^{1)}$ となると ともに，血液浄化療法の目的でもある社会復㷌が重要な 問題となっている2). 血液净化療法の導入期に必ずしも 入院の必要はなく, 重篤な合併症などがなければ外来通 院のままで導入する, いわゆる外来導入融が可能な症例 もあると思われる。また外来導入によって休職期間が短 縮されるならば社会復帰が容易になることが推察され る。そこで，今回私達は末期慢性腎不全症例に対して外 来導入を施行した外来導入例（外来群）について同時期 に入院して導入をした導入例（入院群）を対照として血 液生化学值, 精神面への影響㧍よび社会復帰を比較し, 外来導入の安全性と看護面での問題点について検討した ので報告する。

\section{対象・方法}

対象は 1980 年から 1984 年の 5 年間に当院で血液浄化 療法を施行した基礎疾患が慢性系球体腎炎で重篤な合併 症のない 61 例のうち, 外来通院のままで導入した年齢 23〜 74 歳の男性 8 名, 女性 5 名の外来群 13 例と同じ時 期に入院をしていて導入された 48 例の中から性別抢よ び職業が一致し，年齢の似かよった 22〜 64 歳の男性 8 名，女性 5 名の入院群 13 例計 26 例である（表 1 ）。

対象とした症例に，導入初期は外来，入院の両群とも 血液滤過法を 5 回施行しその後血液透析へ移行した。血 液滤過法は今田ら ${ }^{4}$ の方法に準じた.すなわち, 置換液の 量を初回は $6 l$ とし以後 $2 l$ ずつ増量し第 4,5 回は $12 l$ を用いる血液濾過法を施行した，そして血液浄化療法導 入前, 導入後 4 週抢よび 12 週後の血圧, 体重, 血清尿素 窒素濃度，血清クレアチニン濃度，血清カリウム值，へ マトクリット值を外来群と入院群で比較した。また精神 面への影響とともに社会復帰の程度を労働時間で分け， 週 32 時間以上であれば完全社会復帰，週 32 時間以下， 16 時間以上を部分社会復㷌とした。また社会復帰までの 期間は導入時から仕事を始めるまでとした。したがって 入院群の入院日数も導入日から退院までとした。これら の社会復帰に関する事項と導入期の精神的な影響を対象 症例全員同時に無記名アンケート方式で以下の質問につ いて患者自身に記入させ集計，分析した。

\begin{tabular}{|c|c|c|c|c|}
\hline & \multicolumn{2}{|c|}{ 入院導入 } & \multicolumn{2}{|c|}{ 外来導入 } \\
\hline 年 齢 & \multicolumn{2}{|c|}{$43 \pm 10.3$ 歳 } & \multicolumn{2}{|c|}{$45 \pm 12.1$ 墄 } \\
\hline \multirow[t]{2}{*}{ 性 別 } & 男 性 & 8 名 & 男 性 & 8 名 \\
\hline & 女 性 & 5 名 & 女 性 & 5 名 \\
\hline \multirow[t]{3}{*}{ 職 業 } & 自営業 & 2 名 & 自営業 & 2 名 \\
\hline & 非自営業 & 7 名 & 非自営業 & 8 名 \\
\hline & 主＼cjkstart婦 & 4名 & 主＼cjkstart婦 & 3 名 \\
\hline
\end{tabular}

表 1 対象症例の背景

1. 血液浄化療法を始めた時の不安な事柄

1 ) 経済的な不安，2）死に対する不安，3）净化療 法に対する不安，4）、食事療法に対する不安

2 。患者の背景に関する事柄

1 ) 職業の有無とその職種，2）職業の変化，3）家 族構成と経済的責任

3. 社会復帰に関する事柄

1 ) 社会復帰までの期間，2）社会復帰の程度 結果

1. 外来群, 入院群の検查值の比較

外来群, 入院群の導入前, 導入後 4 週扔よび 12 週の検 査值を図 1 に示した。溢水状態の指標ともいえる血圧, 体重では収縮期血圧が外来群では導入前, 導入後 4 週お よび 12 週でそれぞれ $165.8 \pm 28.6,147.8 \pm 22.3 ， 148.0 \pm$ $20.1 \mathrm{mmHg}$ であり，入院群ではそれぞれ $167.0 \pm 29.0$, $139.8 \pm 16.2,147.5 \pm 90.0 \mathrm{mmHg}$ であった。体重は血液浄 化療法施行前值で外来群がそれぞれ $54.9 \pm 5.6,50.4 \pm 9.6$, $53.2 \pm 10.2 \mathrm{~kg}$, 入院群ではそれぞれ $57.0 \pm 8.1,54.8 \pm 8.3$, $56.1 \pm 8.0 \mathrm{~kg}$ で収縮期血圧, 体重とも両群に統計的な有 意差は認められなかった。また血清尿素窒素濃度は浄化 療法施行前值で外来群では導入前, 導入後 4 週および 12 週でそれぞれ $137.8 \pm 45.7,80.0 \pm 16.4,79.4 \pm 13.1 \mathrm{mg} / \mathrm{d} l$ であり，入院群ではそれぞれ $130.5 \pm 22.6 ， 68.2 \pm 17.3$, $70.0 \pm 17.9 \mathrm{mg} / \mathrm{d} l$ であった。また血清クレアチニン濃度 は浄化療法施行前值で外来群はそれぞれ $12.0 \pm 4.6,9.3 \pm$ $1.5,10.6 \pm 1.9 \mathrm{mg} / \mathrm{d} l$. 入院群ではそれぞれ $14.7 \pm 3.2$, $9.9 \pm 1.7,10.9 \pm 2.9 \mathrm{mg} / \mathrm{d} l$ と血清尿素窒素濃度, 血清クレ アチニン濃度とも両群に差を認めなかった。また血清力 リウム值，へマトクリット值も両群間に差を認めなかっ た。 
2。血液净化療法への導入が精神面に及ぼす影響

血液净化療法が精神面に及ぼす影響をアンケート調査 し図 2 に示した，治療を継続していくことへの不安，食 事制限の不安が外来群ではそれぞれ $84 \%, 77 \%$, 入院群 では 87\%，85\%と両群とも高率に認められていた。また これに比べて少なかったのは両群とも経済的な不安と死 への不安であった。一方穿刺時の痛みや体外循環による 不安といった，いわゆる浄化療法そのものに対する不安 と消化器症状のための食事に対する不安が入院群にそれ ぞれ 70\%, 59\%, 38\%と外来群に比べて有意 $(\mathrm{p}<0.005$ ， $\mathrm{p}<0.01, \mathrm{p}<0.01)$ に高率であった。

3 . 社会復帰状況

血液浄化療法導入後の社会復帰の状況を完全社会復 帰, 部分社会復帰, 休職拈よび失業に分けて図 3 の上段 に示した. 完全社会復州好外来群は $64 \%$, 入院群は $26 \%$ で外来群に有意 $(\mathrm{p}<0.001)$ に高率であった. 部分社会 復帰は両群とも $30 \%$ あっあた.一方休職は入院群に $10 \%$ 認められたのに対し外来群には認められなかった。血液 浄化療法を開始したために退職し新しい仕事にも就いて いない失業は入院群は $34 \%$, 外来群は $6 \%$ で入院群に有 意 $(\mathrm{p}<0.001)$ に高率であった。

4 。社会復帰までの期間

血液浄化療法へ導入した時から社会復兴をするまでの 期間を $0 \sim 6$ 力月, 6 力月〜 12 力月, 1 年 1 年 6 力月, 1 年 6 力月〜 2 年と分けて図 3 の下段に示した. 入院群 では社会復㷌までの期間は 6 力月〜 1 年の $30 \%$ が最も 多く, $0 \sim 2$ 年にわたっていた. 一方, 外来群では失業 した人をのぞいた $94 \%$ のが 0〜6 月月で社会復帰を していな.

\section{考察}

当初, 延命あるいは長期生存が目的であった血液浄化 療法は, 完全社会復帰へとその目標も変わってきた。

全社会復帰者数および完全社会復帰者数は患者数とと もに増加している ${ }^{1,6)}$. しかし，その社会復带率は血液浄 化療法の適応の拡大によって高齢者や合併症のある症例 の導入が増加したこともあり 1980 年からの 5 年間では $60 \%$ 前後を維持している。

社会復帰は生きていく意欲をもたせるうえで重要であ る2゙.また家庭に抢いて生計を支えている人にとっては 経済的自立のために職場への復㷌が不可欠である ${ }^{5)}$. そ こで我々は入院による休職期間の長期化が社会復帰を難 しくしている一因であると考え, 血液浄化療法へ導入す るのに入院を全く必要としない外来導入を試みた。

血液浄化療法導入後の社会復帰の状況を見ると外来導 入を施行した患者に休職者数, 失業者数が著減していた こと, および外来導入患者の $95 \%$ が $0 \sim 6$ 力月で社会復
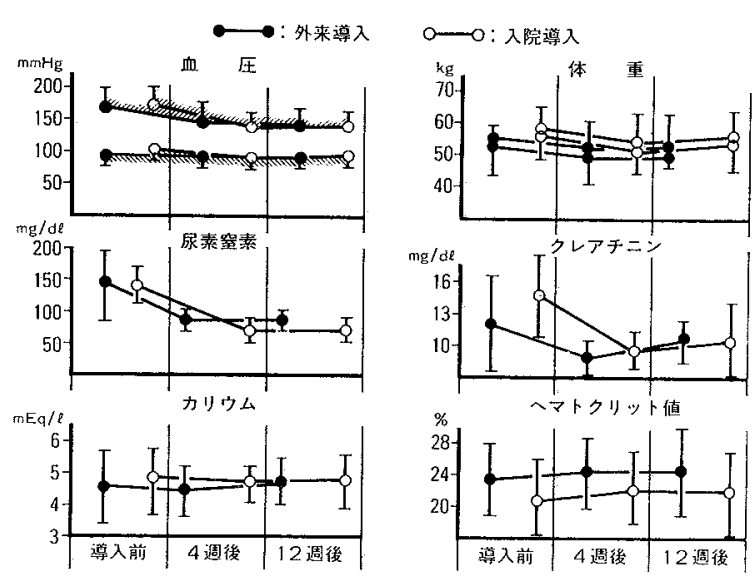

図 1 外来, 入院導入例の導入前, 尊入 4 週书占 び 12 週後の血圧, 体重, 血清尿素窒素濃度, 血清クレアチニン濃度, 血清カリウム濃度, ヘマトクリット值の比較

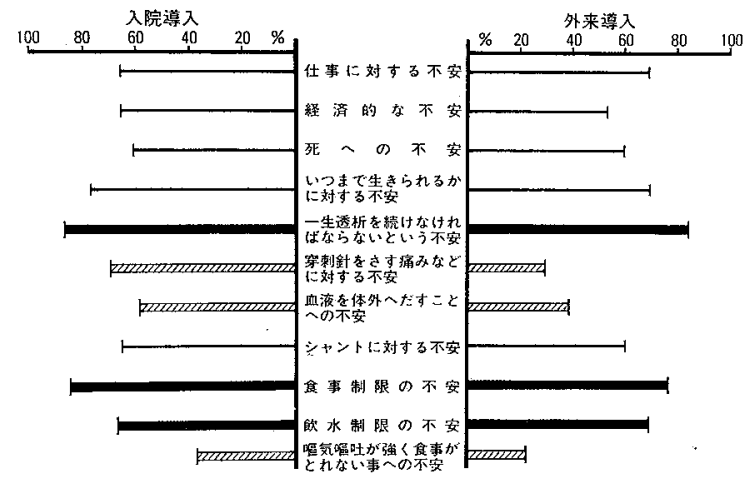

図 2 入院導入例と外来導入例に打ける血液浄化 療法導入時の種々の精神面への影蚃の割合
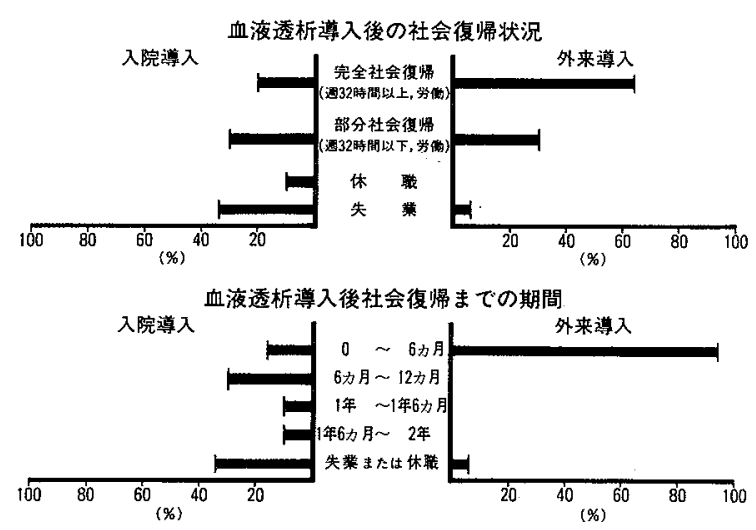

図 3 入院導入例と外来導入例の社会復帰の状況 と期間の割合 
圝していたことを合わせて考えると入院していたことが 早期社会復帰を防げている要因の 1 つだと考えられた。

しかし，外来導入は全ての症例に適店できる訳ではな く症例を選択する必要が市る゙．その条件としては，外来

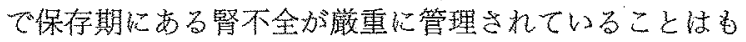
らろんであるが, 高歯者や特別な基礎疾患を有する症例 あるいは重篤な合併症例でないことが条件となる。

末期慢性腎不全で血液浄化療法入導入する患者の大多 数加何らかの強い不安を示すことが報告されてい る ${ }^{7 \sim 10)}$. 今回私達の調查でも同栐な結果が得られた。すな わち，いつまで生きられるか，一生浄化療法を継続しな

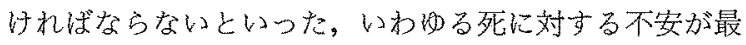
も多く見られた。外来導入㞳入院導入と異なり週 $2 \sim 3$ 回しかも血液浄化療法を施行している前後の $5 \sim 6$ 時間 が患者と接触できる時間である，そのため患者との対話 や指導市るいは教育といったことが不足し前述した死に 対する不安感や恐怖感と血液净化療法そのものに対する 不安感をとり除くことが困難になってくる.これらの不 安感や恐怖感をとり除き円滑に外来導入を施行するには 症例の選択といった治療面のことはも方ろんであるが, 精神面に対する看護が重要となってくる. 看護面での対 策を考えてみると，外来であるために接触時間が短くな ることに対しては慢性監不全の保存療法期加ら外来受誩 時に接触老行う。ほとんどの患者に見られる不安感, 恐 怖感に対しては，早期から病気に対する知識あるいは血 液浄化療法に対する正しい情報を与え，そして医療又 タッフを交えた対話の場を設け安定している患者を含め て交流させることにより不安感, 恐怖感の緩和に努めた。

十分に管理された症例は極めて末期になるまで無症状 に経過する例が少なくないと報告されている。また無症 状に経過した例は, 疼痛に対する恐怖感がより強いと言 われている ${ }^{11)}$. 私達の調查でも穿刺時の疼痛に対する不

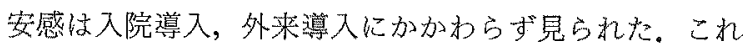
ら肉体的苦痛に対しては，穿刺時に十分注意し血腫を作 らないことが必要である、また透析条件にも注意し不均 衡症候群の予防につとめるといったことで緩和すること が可能であった。以上のことを確実に実行守るために チェックリストを作成する。そしてこれにもとずいて看 護スタッフが統一された指導を行うことで外来導入を安 全に施行することができ,早期社会復㷌が可能であった。

\section{結語}

早期社会復㷌を目的として外来通院のままで血液浄化 療法へ導入する外来導入を施行した結果以下の結猃をえ t.

1）早期社会復帰の面では外来導入が有利であった。

2) 外来導入の適応は保存期に十分管理されているこ
とが必要である。

3）外来導入は患者との接触時間が短くなるため指 導, 教育が不十分になる危険性が亦る。そのため外来受 診時にできるが゙り接触する必要がある。

4) 導入期の患者の不安感, 恐怖感効しては正しい 情報を与えることを，医療スタッフを交えて安定した惠 者を含めて対話を行うことで緩和することができた。

5 ) 保存療法加ら継続した指導, 教育を行うには チェックリストが必要であった。また，交れを用いるこ とで, 外来導入が円滑に施行でき, 早期社会復帰が可能 であった。

本論文の要旨は昭和 60 年 7 月, 第 30 回人工透析研究会総 会において発表した。

\section{文献}

1.) 小高通夫：わが国の透析療法の現況。透析会誌, 19： $1-21,1986$.

2）赤沢美喜子：成人患者の社会復帰, 前田点亮編, 透 析患者の精神・心理面のアア，180-189，日本メディ カルセンター, 1984 。

3）今田聰雄, 長谷川広文, 数田康仁, 堀内 篤, 小木 幸人，河内弥生，西村昌美：導入初期の各種血液浄 化法の比較検討と外来導入について. 緊と透析, 12： 335-339, 1982.

4）今田聰雄，堀内 篤，小木幸人，河内弥生，西村昌 美：末期慢性腎不全に対する導入期血液透析おるび 血液滤過の臨床的検討。基礎と臨床, $15 ： 6459-6466$, 1981.

5）東條静夫，渡辺孝太郎：職場環境. 日本臨床，43： $756-763,1985$.

6）小高通夫：わが国の慢性透析潦法の現沉。透析会誌， 14:295-303, 1982.

7）浅井舅弘, 保崎境夫, 武正健一, 平野正治, 大沢 昫 ; 人工透析の精神医学的諸問題。精神医学, 15:4-17, 1973.

8) Beard, B. H. : Fear of death and fear of life: The dilemma in chronic renal failure. Hemodialysis and kidney transplantation. Arch. Gen. Psychiat., $21: 373-380,1969$.

9）平沢由平, 薄田芳丸, 塚田浩治, 橘 令子：腎と疾 患と精神障害。診断と治療，48：935-940，1973。

10）鳥野弘一：透析患者の心理的側面についての観察。 医学研究, 50:22-43, 1980。

11）二瓶宏，南方 保, 鈴木好夫, 原 茂子, 葛原敬 八郎, 三浦雅弘, 三村信英: 導入時の問題点, 初期 の合併症。日本臨床，43：41-62，1985。 